\title{
Makna Simbolik Ayat-Ayat tentang Kiamat dan Kebangkitan dalam Alquran
}

\author{
Andy Hadiyanto \\ Univesitas Negeri Jakarta \\ abunayeera@gmail.com \\ Umi Khumairoh \\ Univesitas Negeri Jakarta \\ umikhumairoh1995@gmail.com
}

Naskah diterima;16 Juli 2018, direvisi:26 Juli 2018; disetujui: 30 Juli 2018

\begin{abstract}
This research aims to get a symbolic understanding of the meaning of the doomsday and resurrection in the Alquran (eschatological verses) with textual and contextual analysis of these verses. The eschatological verses in the Alquran beside having textual-theological meanings have symbolic meanings. Theological meanings presupposes that the events of the apocalypse, the resurrection, the life of heaven and hell are the areas of faith that must be believed to be a real event of a supernatural nature. While symbolic meanings menyaran on the understanding that the verses are diuturnkan in the context of culture and situation of certain historical conditions that allow the reading of eschatological concepts are contextual. The research uses literature approach and literature review method that is used is structural analysis, based on the theory that the text of al-Alquran consists of various elements forming the structure. This research also uses descriptive qualitative research approach with survey research method. The survey method is used to describe PAI lecturer's understanding of the symbolic meaning of eschatological verses in the Alquran.
\end{abstract}

Key words: textual-theological meaning, symbolic meaning, eschatological verse

\begin{abstract}
Abstrak
Penelitian ini bertujuan untuk mendapatkan pemahaman simbolik tentang makna kiamat dan kebangkitan dalam Alquran (ayat-ayat eskatologis) dengan analisis tekstual dan kontekstual terhadap ayat-ayat tersebut. Ayat-ayat eskatologis dalam Alquran di samping memiliki makna tekstual-teologis juga memiliki makna simbolik. Pemaknaan teologis mengandaikan bahwa peristiwa-peristiwa kiamat, kebangkitan, kehidupan syurga dan neraka adalah wilayah keimanan yang harus diyakini sebagai peristiwa nyata yang sifatnya ghaib. Sedangkan pemaknaan simbolik menyaran pada pemahaman bahwa ayat-ayat tersebut diuturnkan dalam konteks budaya dan situasi kondisi kesejarahan tertentu yang memungkinkan pembacaan terhadap konsep-konsep eskatologis tersebut secara kontekstual. Adapun penelitian ini menggunakan pendekatan sastra dan metode penelaahan sastra yang digunakan adalah analisis struktural, yang berdasarkan teori bahwa teks Alquran terdiri dari bermacam-macam unsur pembentuk struktur. Penelitian ini juga menggunakan pendekatan penelitian kualitatif deskriptif dengan metode penelitian survey. Metode survey digunakan untuk mendeskripsikan pemahaman dosen PAI terhadap makna simbolik ayat-ayat eskatologis dalam Alquran.
\end{abstract}

Kata kunci: makna tekstual-teologis, makna simbolik, ayat-ayat eskatologi 


\section{Pendahuluan}

Merupakan pandangan umum umat Islam, bahwa Alquran diturunkan secara bertahap menyesuaikan dengan realita dan kondisi yang dihadapi oleh da'wah Islam kala itu. Menurut Alquran sendiri, hikmah diturunkannya Alquran secara bertahap adalah untuk meneguhkan perasaan Muhammad sehingga ia senantiasa merasa dalam komunikasi intensif dengan Tuhan (Majma' al-Malik Fahd, Al-Makky wa al-Madany, hal.1). Tidak hanya itu, Alquran turun secara bertahap selama kurang lebih 23 tahun untuk memberikan arahan tentang reformasi sosial budaya secara komprehensif dan terukur (Al-Qathan, hal. 51). Arahan-arahan tersebut disampaikan dengan memperhatikan situasi, tempat, dan audiens Alquran pada saat peristiwa nuzūl.

Alquran tidak turun dalam ruang hampa sejarah, artinya ia turun dalam konteks budaya tertentu yang telah mengakar. Sebagai pesan Tuhan, Alquran turun dalam konteks masyarakat Arab abad ke tujuh dengan berbagai tradisi dan realita budayanya kala itu (Sodiqin, Antropologi Al Qur'an, 2008, hal. 12). Pada masa Rasulullah ayat-ayat Alquran yang diwahyukan selalu menimbulkan dinamika wacana dalam masyarakat. Ayat-ayatnya selalu terlibat dalam sebuah dialog kehidupan secara dinamis dan terbuka. Dialog antara Alquran dengan realitas bangsa Arab kala itu merupakan sebuah keniscayaan, karena bangsa Arab sendiri merupakan sebuah bangsa yang telah mengalami kemajuan budaya dan peradaban. Pergumulan yang sangat intens antara alQur'an dengan dinamika sosial sangat mencolok pada masa Rasul Muhammad. Ayat-ayat al-Qur'an yang diturunkan secara bertahap membuatnya mampu berdialog dengan realitas sosial kala itu, akibatnya al-Qur'an tidak sekedar dinikmati keindahan gramatika dan bahasanya saja melainkan dapat membangkitkan kesadaran dalam diri pendengar dan pembacanya untuk bergerak dan berbuat sesuai arahan-arahan yang diberikannya (Hadiyanto, 2015, hal. 1).

Pesan-pesan awal Alquran yang turun di Makkah menekankan kepada ketauhidan, ketakwaan, masalah eskatologis, ibadah ritual, dan etika sosial. Hal ini sangat relevan dengan realitas masyarakat Makkah yang menyembah berhala (politeisme), orientasi pada kehidupan profan, dan melakukan praktik-praktik sosial yang eksploitatif. Ajaran tentang ketauhidan menjadi dasar ajaran Islam. Prinsip ini mengajarkan kepada manusia untuk tunduk hanya kepada Tuhan Yang Maha Esa, sehingga menumbuhkan sikap sosial yang humanis dan egaliter. Sikap ini akan menciptakan rasa kesamaan derajat dan menghilangkan ketidakadilan sosial dalam masyarakat. Sebaliknya, Politeisme dalam 
masyarakat Makkah mengakibatkan pandangan hidup yang serba material. Status sosial seseorang dilihat berdasarkan harta kekayaannya, sehingga kepercayaan ini mengakibatkan terjadinya ketidakadilan dalam masyarakat (Siddiqi, 1994, hal. 18).

Ajaran lain yang ditransformasikan pada masyarakat pagan Arab melalui ayat-ayat Alquran adalah tentang masalah eskatologis. Alquran mengenalkan hari akhir dan segala yang berkaitan dengannya, seperti hari kebangkitan, hari pembalasan, serta surga dan neraka. Dalam pesan-pesan Alquran, terdapat kesejajaran antara keyakinan kepada keesaan Tuhan dengan hari akhir. Hal ini terlihat dalam beberapa ayat Alquran, kalimat “yaum al-ākhir" disebutkan sebanyak 24 kali, sedangkan kata "ākhirat" disebutkan sebanyak 115 kali (Sodiqin, 2008, hal. 87). Ajaran eskatologis tersebut berseberangan dengan pemikiran tradisional Arab, yang menganggap bahwa keyakinan eskatologis sebagai upaya pelarian dari ketidakmampuan menghadapi persaingan hidup. Bagi mereka, ajaran ini hanya pantas bagi kelompok yang secara ekonomi menempati posisi menengah ke bawah. Mereka pun meragukan konsep eskatologis tersebut, bahkan tidak mempercayainya.

Alquran berusaha mengemukakan bukti-bukti logis tentang adanya hari akhir. Berdasarkan keadilan, setiap perbuatan harus mendapat imbalannya. Doktrin tentang eskatologis merupakan upaya untuk mereformasi kondisi moral masyarakat. Penerimaan akan realitas adanya hari akhir berhubungan dengan realisasi adanya keadilan Tuhan (Nasr, 2002, hal. 245). Keyakinan terhadap kehidupan setelah mati dapat mendorong orang untuk berbuat kebajikan. Nampaknya seruan yang massif dari al-Qur'ân periode Makkiyyah untuk menginternalisasikan nilai-nilai eskatologis ditujukan untuk mengkritik tatanan sosial budaya yang tidak bermoral kala itu.

Seringkali pembaca Alquran terjebak pada pemaknaan ayat-ayat Alquran secara tekstual, dan berhenti pada informasi tersurat sebagaimana dipaparkan oleh Alquran. Bila mengacu pada kesepakatan ulama bahwa Alquran terdiri dari lapisan-lapisan makna, maka pemahaman yang hanya sebatas pada makna tersurat seringkali dianggap sebagai bentuk simpifikasi bahkan distorsi terhadap pesan Alquran tersebut. Terkait dengan ayat-ayat eskatologis, mayoritas pembaca Alquran akan menganggap ayat-ayat tersebut sedang memberikan informasi tentang kehidupan pasca kematian. Bahwa setiap manusia akan mati dan dimintai peratnggungjawaban atas segala amal perbuatannya.

Sebagai kitab hidayah dan da'wah, Alquran bertujuan untuk mempengaruhi pendengar atau pembacanya agar mau menerima gagasan yang diajukannya dan 
mengamalkannya dalam kehidupan. Oleh karenanya Alquran selalu menggunakan dualisme pendekatan dalam menyeru manusia, ia tidak hanya menyentuh aspek kognitif namun juga menyentuh aspek afektif secara bersamaan. Gagasan-gagasan Tuhan disampaikan oleh Alquran secara argumentatif, logis dan rasionil tetapi menggunakan gaya bahasa dan tehnik pengungkapan yang menyentuh perasaan dan emosi pendengar atau pembacanya, sehingga ia menjadi terkesan dan terpengaruh dengan gagasan tersebut. Ini membuktikan bahwa Alquran menggunakan pendekatan sastra dalam menyampaikan pesan-pesan Tuhan tentang gagasan-gagasannya mengenai kehidupan di dunia dan akhirat (Badwi, hal. 37).

Dipilihnya bahasa Arab sebagai bahasa Alquran mengindikasikan bahwa pada mulanya Alquran mengajukan gagasannya terhadap orang-orang Arab, sekaligus mewakili paradigma sosial budaya Arab (Amin, 1975). Bertolak dari itu, Alquran banyak menyampaikan pesan dan gagasannya dengan menggunakan tehnik penyampaian dan gaya bahasa yang diakrabi orang Arab, dan mengacu pada nalar bangsa Arab ketika itu. Salah satu tehnik komunikasi yang dimiliki bangsa Arab kala itu adalah penggunaan narasi yang mengintegrasikan konsep dalam bahasa simbolik. Sebagai contoh, untuk memotivasi agar manusia mau tundauk dan patuh terhadap Tuhan, Alquran mendeskripsikan secara naratif tentang ketaatan alam semesta terhadap ketentuan Tuhannya. Untuk memberikan efek takut yang mendalam agar manusia tidak melakukan praktek riba misalnya, Alquran menggunakan perumpaan pelaku riba dengan kepalakepala syetan. Hal-hal di atas mengindikasikan bahwa di balik lokusi dan perlokusi suatu ayat terdapat ilokusi yang diduga merupakan substansi dari suatu ayat. Suatu ungkapan dalam Alquran dapat berimplikasi pada eksplorasi makna yang luas dan dalam. Atas dasar itu, pengungkapan ayat-ayat eskatologis dalam Alquran diduga juga mengandungmakna yang lebih dalam, bukan hanya sekedar berbicara tentang kematian, kebangkitan, syurga-neraka, dan pertemuan dengan Allah semata. Apabila ayat-ayat tersebut dibaca untuk scope individu maka pemaknaan di atas dapat diterima, namun bila dipahami bahwa Alquran juga berbicara tentang komunitas dan masyarakat, maka pemahaman terhadap ayat-ayat eskatologis perlu dikaji ulang.

\section{Kajian Teoritik}

\section{A. Konsep Eskatologi}

Eskatologi berasal dari kata eschalos dalam bahasa Yunani yang berarti 'yang terakhir', 'yang selanjutnya', dan 'yang paling jauh'. Secara umum merupakan 
keyakinan yang berkaitan dengan kejadian-kejadian akhir hidup manusia seperti kematian, hari kiamat, hari berakhirnya dunia, saat akhir sejarah, dan lain-lain. Ketika kata eschalos disandingkan dengan kata logos yang menjadi eskatologi dalam bahasa Indonesia berarti ilmu atau pengetahuan tentang hal-hal akhir, hal-hal pamungkas, atau yang menyangkut realitas akhirat sebagai akhir kehidupan seperti kematian, kebangkitan, pengadilan terakhir, serta kiamat sebagai akhir dunia.

Dalam filsafat Islam perbincangan tentang eskatologi menjadi sebuah bidang tersendiri sebagai refleksi pengungkapan dimensi-dimensi metafisis dan ketuhanan yang berlandaskan pada ayat-ayat yang termaktub di dalam Alquran. Walaupun demikian pembahasan tentang eskatologi ini mengundang perdebatan yang sangat krusial di antara para pemikir Islam, filsuf, dan lain sebagainya. Seperti Imam al-Ghazālī yang cenderung mengkafirkan para filsuf yang diwakili oleh al-Fārābī dan Ibn Sīnā karena tiga sebab yang salah satunya adalah persoalan eskatologis.

Di samping itu, dari perbincangan seputar persoalan-persoalan eskatologi melahirkan asketisme. Sebuah pandangan hidup yang menjadikan alam akhirat sebagai tujuan utama dalam hidupnya tanpa melupakan kewajibannya di alam dunia: "Dan carilah pada apa yang telah dianugerahkan oleh Allah kepadamu (kebahagiaan) negeri akhirat, dan janganlah kamu melupakan bahagianmu dari (kenikmatan) duniawi dan berbuat baiklah (kepada orang lain) sebagaimana Allah telah berbuat baik kepadamu, dan janganlah kamu berbuat kerusakan di (muka) bumi. Sesungguhnya Allah tidak menyukai orang-orang yang berbuat kerusakan.”

Pembahasan terhadap hadis Jibril yang diriwayatkan oleh Umar RA menunjukkan bahwa pilar konsep kebaragamaan ada empat, yaitu: Iman (aqīdah), Islam (shari 'ah), Iṇsān (țarīqah), dan Sa'ah (fiqh tahāwulāt). Kajian tentang eskatologi dalam hal ini merupakan wilayah garapan ilm sa'ah, yang menjelaskan tentang tanda-tanda dekatnya kiamat serta terjadinya kiamat. Menurut Abu Bakr al-Adany, ilmu tentang kiamat ini berbicara tentang tanda-tanda kiamat besar, kiamat sedang, dan kiamat kecil (Ali alMashhur, 2015, hal. 18).

Kajian Eskatologi dalam Islam, sejalan dengan isyarat hadis di atas menurut AlAdany lagi difokuskan pada kajian tentang:

a. Fiqh Nawaqị̣ wa Naqaị̣ wa asbab al-fitan wa Muḍillatuhā (memahami makna huru-hara dan kontradiksi sosial akibat fitnah) 
b. Fiqh al-ishārat wa al-Bisharat wa al-Nazārat wa al-Hașānāt wa Sharaf al-'adālah wa al-sanad (memahami makna berita gembira dan peringatan)

c. Fiqh Mustajaddat al-Ulūm al-Nazariyah wa al-Tatbiqiyyah wa al-Tathaqafät (memahami isyarat tentang perkembangan Sains dan teknologi)

d. Fiqh al-Rabth al-Shar'iy baina al-Diyānah wa al-Tärikh (memahami benang merah antara wacana keagamaan dan realitas sejarah) (Ali al-Mashhur, 2015, hal. 19-23). Dari uraian di atas dapat disimpulkan bahwa penjelasan Alquran dan al-Hadis tentang kehancuran, huru-hara, gonjang-ganjing akhir zaman dan berbagai peringatan serta berita gembira diduga sebagai penjelasan simbolik tentang bangkit dan mundurnya sebuah peradaban dan kebudayaan umat manusia. Dengan kata lain, wacana-wacana keagamaan tentang hari akhir sejatinya dapat diambil benang merahnya dengan kontesk historis masa lalu untuk memprediksi masa depan.

\section{B. Semiotika : Metode Pemaknaan Simbolik}

\section{Pengertian Semiotika}

Banyak definisi dan pengertian yang diberikan para ahli terhadap semiotik. Mansur Pateda menuliskan bahwa semiotik adalah teori tentang sistem tanda. Nama lain semiotik adalah semiologi dari bahasa Yunani semeion yang bermakna tanda, mirip dengan istilah semiotik (Pateda, 2001, hal. 28). Alex Sobur menganggap semiotik sebagai suatu model ilmu sosial yang memahami dunia sebagai sistem hubungan yang memiliki unit dasar yang disebut tanda (Sobur, 2003, hal. 87). Semiotik dapat disimpulkan sebagai ilmu atau metode analisis untuk mengkaji tanda. Tanda adalah sesuatu yang mewakili sesuatu yang lain yang dapat berupa pengalaman, pikiran, perasaan, gagasan, dan lain-lain (Nurgiyantoro, 1998, hal. 40).

\section{Pemikiran-Pemikiran Tentang Semiotika}

Peletak dasar teori semiotik ada dua orang, yaitu Ferdinand de Saussure dan Charles Sanders Peirce. Saussure mempergunakan istilah semiologi, sedang Peirce memakai istilah semiotik. Keduanya berasal dari latar belakang keilmuan dan geografis yang berbeda. Saussure dari benua Eropa dikenal sebagai bapak Linguistik Modern, dan Peirce dari benua Amerika dikenal sebagai ahli filsafat.

Saussure dalam bukunya Cours de Linguistique Generale (1916) memusatkan perhatian pada sifat dan prilaku tanda-tanda linguistik. Saussure mendefinisikan tanda linguistik sebagai entitas dua sisi. Sisi pertama disebut penanda (signifier) yaitu aspek material dari sebuah tanda, sebagaimana kita menangkap bunyi saat orang berbicara. 
Citra bunyi menurut Saussure merupakan penanda verbal. Sisi kedua adalah petanda (signified), merupakan konsep mental. Jika kita menyebut kata "anjing" apa yang terkesan pada pendengar bukanlah anjing yang sesungguhnya, tetapi konsep tentang “anjing/ keanjingan".

Menurut Saussure tanda dapat bekerja karena ada difference sehingga dapat dibedakan satu tanda dengan tanda-tanda lainnya. Menurutnya lagi setiap fenomena bahasa dibentuk oleh dua faktor: Parole (ekspresi kebahasaan) dan langue (sistem pembedaan di antara tanda-tanda). Langue sebagai sistem pembedaan tanda-tanda mengenal batas-batas kombinasi dan substitusi elemen bahasa, sehingga terbentuk hubungan sintagmatik atau paradigmatik. Dalam sebuah wacana kata-kata saling berhubungan sesuai dengan sifat linearitas bahasa, dan tidak mungkin orang melafalkan dua unsur sekaligus. Di pihak lain, di luar wacana, kata-kata yang mempunyai kesamaan berasosiasi dalam ingatan dan menjadi bagian kekayaan tiap individu (Nurgiyantoro, 1998, hal. 45).

Sementara teori Peirce mengatakan bahwa sesuatu itu dapat disebut sebagai tanda jika ia mewakili sesuatu yang lain. Sebuah tanda haruslah mengacu/ mewakili sesuatu yang disebut obyek/ acuan (denotatum/ referent). Tanda tersebut harus ditangkap dan dipahami dalam perspektif kesaling hubungan antara tanda itu sendiri, ground atau sebuah tata acuan atau konvensi yang mendasari pemahaman tanda, denotatum yaitu suatu kelas dari acuan yang ditunjuknya (Sukiman , 2003, hal. 114), dan pemahaman makna yang timbul dalam kognisi lewat interpretasi yang disebut interpretant (Nurgiyantoro, 1998, hal. 41).

Proses perwakilan itu disebut semiosis, dimana suatu tanda berfungsi mewakili sesuatu.Proses semiosis terjadi secara terus menerus sehingga sebuah interpretant menghasilkan tanda baru yang mewakili obyek yang baru pula dan akan menghasilkan interpretant yang lain lagi.

\section{Ancangan Semiotika Sastra}

Wilayah cakupan ilmu semiotika jika ditelusuri lebih jauh dapat meliputi bidang keilmuan, keagamaan, estetik, dan budaya. Pengkajian semiotika di bidang estetis mencakup semua jenis seni termasuk sastra. Dalam pengkajian karya sastra, semiotika estetis akan menyasar pada bidang kisah rekaan (prosa fiksi), susastra lakon (drama), dan puisi. 
Ancangan semiotika sebagai salah satu alternatif untuk mengkaji karya sastra muncul sejak perhatian sastra memfokuskan diri pada hubungan antara penanda dan petanda dalam memahami makna. Ia muncul sebagai penengah perdebatan antara kaum formalis yang menganggap karya sastra terus menerus berubah dan tidak otonom dalam proses komunikasi, dengan kaum strukturalis yang beranggapan bahwa karya sastra secara otonom merupakan tanda yang memungkinkan terjadinya komunikasi.

Karena sastra memiliki watak otonom dan komunikatif, maka sebagaimana dualisme semiotika seperti yang telah dikupas di atas, karya sastra dapat ditinjau dalam ancangan semiotik secara struktural dan komunikatif. Watak otonom sastra dapat ditinjau secara struktural dan watak komunikatif ditinjau secara ekstrinsik (kontekstual).

Secara otonom pengkajian semiotika sastra dapat menggunakan pokok-pokok pikiran Charles Morris (1971), menurutnya ada empat macam yang dikaji secara semiotik: (1) hubungan antar lambang, (2) penafsiran lambang, (3) maksud lambang, (4) cara pemakaian lambang (Santosa , 1993, hal. 20).

\section{Metodologi Penelitian}

Paradigma yang dipergunakan dalam penelitian ini adalah paradigma rasionalistik yang memandang realitas sosial sebagaimana dipahami oleh peneliti berdasarkan teoriteori yang ada dan didialogkan dengan pemahaman subyek yang diteliti/ data empirik. Paradigma ini banyak digunakan oleh penelitian filsafat, bahasa, agama, dan komunikasi (Eriyanto, 2001).

Menurut paradigma rasionalistik ini, Alquran sebagai wahyu Tuhan yang diterima Muhammad sebagai komunikator tidak berada dalam ruang hampa sejarah. Muhammad adalah manusia sejarah yang dipengaruhi oleh konteks sosial budaya, politik, dan ekonomi di mana ia hidup. Faktor-faktor tersebut sangat mempengaruhi Muhammad dalam memahami dan mengimplemantasikan wahyu Tuhan tersebut, bahkan mempengaruhi jenis ayat, ketentuan ayat, dan gaya bahasa ayat yang turun kepadanya.

Mengacu pada tujuan penelitian di atas, maka penelitian ini akan menggunakan pendekatan sastra untuk menelaah ayat-ayat eskatologis yang terdapat dalam surat makiyah dan Madaniyah. Adapun metode penelaahan sastra yang digunakan adalah analisis struktural, yang berdasarkan teori bahwa teks Alquran terdiri dari bermacammacam unsur pembentuk struktur (Pradopo, Penelitian Sastra dengan Pendekatan semiotik dalam Jabrohim: Metodologi Penelitian Sastra, 2001, hal. 21). 
Penelitian ini juga menggunakan pendekatan penelitian kualitatif deskriptif dengan metode penelitian survey. Metode survey digunakan untuk mendeskripsikan pemahaman dosen PAI terhadap makna simbolik ayat-ayat eskatologis dalam Alquran. Dalam penelitian ini, aspek-aspek yang berhubungan dengan pemahaman dosen PAI tersebut dideskripsikan. Pendekatan seperti ini tidak dimaksudkan menarik generalisasi, karena memang dalam penelitian survey ini tidak menggunakan dan tidak melakukan pengujian hipotesis. Tetapi lebih banyak mendeskripsikan makna-makna dari aspekaspek yang terkait sehingga membentuk satu penjelasan yang utuh mengenai suatu kasus.

Data dalam penelitian ini adalah seluruh sistem tanda bahasa yang terdapat dalam surat Makiyah dan Madaniyah yang di dalamnya terdapat ayat-ayat eskatologis. Datadata yang berupa tanda bahasa tersebut dapat dikatagorikan ke dalam beberapa unit pengamatan yaitu: makna tektual-teologis, dan makna simboliknya. Di samping itu, data dalam penelitian ini berupa pandangan dan pemahaman dosen PAI tentang makna simbolik ayat-ayat eskatologis dalam Alquran.

Data penelitian ini diperoleh dari mushaf Alquran al Karim pada beberapa surat makiyah dan Madaniyah, beserta terjemahan dan penafsiran-penafsirannya. Adapun data-data penunjang diperoleh dari buku-buku tentang kiamat, kebangkitan, syurga, dan neraka.

Teknik pengumpulan data pandangan dosen PAI tentang makna simbolik ayat-ayat eskatologis dilakukan dengan dua cara: kuesioner dan wawancara. Kuesioner disebarkan secara online kepada beberapa dosen PAI untuk menggali pemahaman mereka tentang topik-topik seputar simbolisasi makna ayat-ayat esktologis

Wawancara dilakukan terhadap responden yang mengsisi kuesioner secara purposive, dengan pertimbangan bahwa informan tersebut memiliki informasi yang mendalam tentang tema yang diusung dalam penelitian ini.

Data-data yang diperoleh melalui prosedur di atas dianalisis melalui beberapa tahap yakni, reduksi, penyajian data dan penarikan kesimpulan.

\section{Konteks Sosio Historis Ayat-Ayat Eskatologis}

Ayat-ayat eskatologis dalam Alquran adalah ayat-ayat yang berbicara tentang akhirat, hari akhir. Term al- yaum al-ākhir secara semantik terdiri dari dua kata, yaum dan akhir. Menurut al-Asfahani, kata yaum mengadung dua pemahaman, pertama mengacu pada waktu perjalanan matahari dari terbit sampai terbenam (bersifat 
kuantitatif), kedua mengacu kepada sebuah masa atau waktu yang tidak tertentu (bersifat kualitatif). Term yaum al-ākhir seharusnya dipahami sebagai hari kualitatif bukan kuantitatif.

Term al-yaum al-ākhir di Alquran terulang sebanyak 26 kali, yang seluruhnya dirangkai dengan term al-imān billah (iman kepada Allah), seakan inti iman itu hanya dua ini. Penyebutan hari akhir secara spesifik adalah dimaksudkan untuk menumbuhkan dan mendorong seseorang agar senantiasa berbuat kebaikan. Dalam Alquran juga ditemukan term lain yang biasa dipahami sama dengan al-yaum al-ākhir, yaitu al$\bar{a}$ khirah yang di dalam Alquran terulang sebanyak 115 kali. Term al-ākhirah mengacu kepada sebuah kehidupan lain yang berbeda sama sekali dengan kehidupan dunia, baik sifat maupun karakteristiknya, kecuali satu ayat yaitu : Qs. ad- Duha/93 :4. Kata alākhirah disini berarti akhir perjuangan nabi Muhammad SAW yang menjumpai kemenangan-kemenangan, sedang permulaannya penuh dengan kesulitan-kesulitan.

Term al-ākhirah merupakan antonym dari al-dun-ya. Artinya ketika disebutkan alākhirah maka ia mengacu kepada sebuah kehidupan yang hakiki dan kekal, sebagai lawan dari ad-dun-ya yakni kehidupan yang artifisial dan bersifat sementara. Penyebutan al-yaum al-ākhir, yang dirangkai dengan iman kepada Allah, pada hakikatnya dimaksudkan sebagai hari perhitungan (al-hisab) dan pembalasan (al-jaza'), sehingga oleh Alquran ia dijadikan sebagai sarana yang efektif untuk menumbuhkan kejujuran, ketakwaan, kedermawanan, berani berkorban demi kebenaran dan kadilan, dan sebagainya. Begitu juga, ia bisa dijadikan tameng dari perilaku-perilaku buruk, misalnya kemunafikan, riya, dan sebagainya.

Ayat-ayat eskatologis dalam Alquran, kebanyakan berasal dari ayat-ayat Makkiyyah. Sesuai dengan konteks keagamaan sosial masyarakat yang dihadapi Nabi Muhammad kala itu, masyarakat Makkah Quraisy tidak mengakui adanya hari akhir dengan berbagai unsurnya, seperti balasan pahala dan surga bagi yang berbuat baik selama di dunia, dan siksa bagi orang yang berbuat dosa di dunia. Karena mereka tidak mempunyai kepercayaan akan hari akhir, Alquran tentu saja menggunakan bahasa yang retoris untuk menegaskan keberadaanya, sesuai dengan keahlian mereka, yang terkenal dengan keahlian sastra (Aksin Wijaya, Metode Tafsir Nuzuli Darwazah, hal.56-57).

Politeisme dalam masyarakat Makkkah mengakibatkan pandangan hidup yang serba material. status sosial seseorang dilihat berdasarkan harta kekayaannya, sehingga kepercayaan ini mengakibakan terjadinya ketidakadilan dalam masyarakat. Di samping 
itu, kepercayaan ini juga membuat orang kehilangan rasa hormat dan percaya pada takhayul, sehingga sulit bagi mereka untuk menerima kebenaran (Sodiqin, 2008, hal. 8586).

Ajaran lain yang ditransformasikan pada masyarakat pagan Arab adalah tentang masalah eskatologis. Alquran mengenalkan hari akhir dan segala yang berkaitan dengannya, seperti hari kebangkitan, hari pembalasan, serta surge dan neraka. Dalam pesan -pesan Alquran terdapat kesejajaran antara keyakinan kepada keesaan Tuhan dengan hari akhir. Hal ini terlihat dalam beberapa ayat Alquranyang mempersandingkan kedua kalimat tersebut. Bahkan kedua kalimat itu seakan-akan mewakili rukun-rukun iman lainnya.

Ajaran-ajaran eskatologis diwahyukan untuk mengingatkan masyarakat Arab yang memprioritaskan kehidupan duniawi semata. Mereka tidak pernah berpikir tentang kehidupan setelah mati, karena hal itu dianggap sebagai delusi. Kedudukan dan kekayaan membutakan mereka untuk berpikir tentang makna dan tanggung jawab kehidupan.

\begin{tabular}{|l|l|l|}
\hline Periode & Surat-Surat & Tema \\
\hline $\begin{array}{l}\text { Fase awal- } \\
\text { perkenalan }\end{array}$ & $\begin{array}{l}\text { Al-Fātiḩah, al-'Ala, al-'Alaq, } \\
\text { al-Fil, Quraisy, al-Așr, al-Tin, } \\
\text { al-Takathur, al-'adiyāt }\end{array}$ & $\begin{array}{l}\text { Pengenalan tentang Allah, } \\
\text { Kenabian, mengingatkan } \\
\text { bangsa Quraisy tentang } \\
\text { karunia Allah, dan } \\
\text { menyampaikan wacana } \\
\text { tentang hari kebangkitan }\end{array}$ \\
\hline $\begin{array}{l}\text { Fase kedua- } \\
\text { penyiapan } \\
\text { psikologis }\end{array}$ & Al-muzzammil & $\begin{array}{l}\text { Arahan untuk nabi dan } \\
\text { peringatan bagi Quraisy atas } \\
\text { kemaksiyatan mereka selama } \\
\text { ini }\end{array}$ \\
\hline $\begin{array}{l}\text { Fase ketiga- } \\
\text { Permulaan } \\
\text { dakwah } \\
\text { (peringatan) }\end{array}$ & Al-muddaththir & Idem \\
\hline $\begin{array}{l}\text { Fase keempat- } \\
\text { kesinambungan } \\
\text { dakwah }\end{array}$ & $\begin{array}{l}\text { Al-Qāri'ah, az-zalzalah, al- } \\
\text { infițar, al-inshiqāq, al-takwìr, } \\
\text { asy-syams, al-lail, ath-thariq, } \\
\text { al-fajr, al-balad, al-qiyāmah, } \\
\text { al-naba', Qaf, al-wāqi'ah, al- } \\
\text { Ghashiah, al-hāqqah, al- } \\
\text { mutagfifin, 'abasa, al- } \\
\text { mursalāt, al-jin, al-falaq, al- }\end{array}$ & $\begin{array}{l}\text { Mengajak untuk mengimani } \\
\text { hari akhir, menegaskan akan } \\
\text { adanya kebangkitan, ancaman } \\
\text { bagi mereka yang ingkar, janji } \\
\text { harapan bagi mereka yang } \\
\text { beriman, dan menenangkan } \\
\text { nabi bahwa Allah bersamanya }\end{array}$ \\
\hline
\end{tabular}




\begin{tabular}{|l|l|l|}
\hline & $\begin{array}{l}\text { nas, al-insān, al-mulk, yasin, } \\
\text { al-rahman, al-najm, al-qalam, } \\
\text { al-țur, nuh, mal-qamar, al- } \\
\text { duha, al-inshirah, al-humazah, } \\
\text { dan al-qadr }\end{array}$ & \\
\hline $\begin{array}{l}\text { Fase kelima- } \\
\text { diversivikasi } \\
\text { audiens dakwah }\end{array}$ & $\begin{array}{l}\text { Șad, al-ṣafat, al-nāzi'āt, al- } \\
\text { zariyāt, al-ahqaf, al-jatsiyah, } \\
\text { fathir, fushillat, al-dukhan, al- } \\
\text { zukhruf, ghafir, Maryam, al- }\end{array}$ & $\begin{array}{l}\text { Memperluas cakupan dakwah, } \\
\text { dan melanjutkan janji dan } \\
\text { ancaman bagi bangsa Quraisy }\end{array}$ \\
& $\begin{array}{l}\text { ikhlās, al-kahf, saba', al- } \\
\text { kāfirūn, luqmān, al-naml, al- } \\
\text { hijr, țaha, al-sajdah, al- } \\
\text { mu'minūn, al-ma'ārij, al- } \\
\text { furqan, al-zumar, al-a'rāf, }\end{array}$ & \\
& $\begin{array}{l}\text { yunus, Ibrāhim, yusuf, al- } \\
\text { anbiyā', dan al-kautsar }\end{array}$ & \\
\hline
\end{tabular}

Dalam pemikiran tradisional Arab, ajaran ekstatologis dianggap sebagai upaya pelarian dari ketidakmampuan menghadapi persaingan hidup. Ajran ini hanya pantas bagi kelompok yang secara ekonomi menempati posisi menengah kebawah. Mereka pun meragukan konsep ekstagologis tersebut, bahkan tidak memercayainya.

Alquran berusaha mengemukakan bukti - bukti logis tentang mendapat imbalannya. Disamping itu, Alquran juga menjawab keraguan mereka akan datangnya hari-hari akhir. Dari ayat-ayat tersebut, ajarannya dengan melibatkan kemampuan penalaran masyrakat penerimanya. Meskipun yang disampaikan termasuk sesuatu yang immaterial (gaib), namun penjelasannya menggunakan media yang material. Dalam masyarakat yang materialis seperti Makkah, strategi ini sangat relavan dengan konteks.

Doktrin tentang eskatologis merupakan upaya untuk mereformasi kondisi moral masyarakat. Penerimaan akan realitas adanya hari akhir berhubungan dengan realisasi akan realitas adanya keadilan tuhan. Keyakiann terhadap kehidupan setelah mati dapat mendorong orang untuk berbuat kebajikan. Dari ajaran ini, akan dihasilkan tatanan kehidupan yang bermoral (Sodiqin, 2008, hal. 86-88).

Apabila dirunut secara kronologis, maka konsep-konsep eskatologis telah diperkenalkan oleh Alquran sejak permulaan periode Makkah hingga akhir periode ini. Sebagaimana terlihat dalam tabel berikut:

Teknik yang dipergunakan oleh Alquran dalam menyampaikan konsep eskatologis dapat dilihat dalam table berikut: 


\begin{tabular}{|c|c|c|}
\hline No & Teknik & Contoh surat \\
\hline 1 & $\begin{array}{l}\text { Penggambaran secara kongkrit tentang } \\
\text { kehancuran alam semesta dalam } \\
\text { peristiwa kiamat yang bersifat materil- } \\
\text { kongkrit }\end{array}$ & $\begin{array}{l}\text { Al-qari'ah,al-zalzalah, al-infithar, } \\
\text { al-insyiqaq, at-takwir, al- } \\
\text { waqi'ahal-fajr,al-qiyamah, al- } \\
\text { mursalat,al-haaqqah,an-naba', } \\
\text { yasin, at-thur, ar-rahman,dan qaf }\end{array}$ \\
\hline 2 & $\begin{array}{l}\text { Konfirmasi tentang kepastian adanya } \\
\text { kebangkitan, dan adanya penentangan } \\
\text { terhadapnya }\end{array}$ & Idem \\
\hline 3 & $\begin{array}{l}\text { Penggambaran secara kongkrit tentang } \\
\text { syurga dan neraka, dengan tujuan targhib } \\
\text { dan tarhib }\end{array}$ & $\begin{array}{l}\text { Al-waqiah,al-ghasiyah, al- } \\
\text { mursalat,al-haqqah, abasa, } \\
\text { arrahman, al-muthafiffin,yasin, al- } \\
\text { insan,dan ath-thur }\end{array}$ \\
\hline 4 & $\begin{array}{l}\text { Memberikan janji (harapan) untuk orang } \\
\text { beriman dan ancaman untuk orang kafir }\end{array}$ & Idem \\
\hline 5 & $\begin{array}{l}\text { Afirmasi bahwa semua tindakan kita } \\
\text { akan dievaluasi dan diberikan balasan }\end{array}$ & $\begin{array}{l}\text { Al-qaria'h,ath-thariq, al-zalzalah, } \\
\text { an-naba',an-najm,dan al-qamar }\end{array}$ \\
\hline 6 & Menceritakan kisah-kisah masa lalu & $\begin{array}{l}\text { Asshoffat, al-kahf, saba', al-a'raf, } \\
\text { an-naba', }\end{array}$ \\
\hline 7 & $\begin{array}{l}\text { Afrirmasi bahwa urusan kepatuhan dan } \\
\text { ketaatan pada pedoman agama adalah } \\
\text { pilihan manusia }\end{array}$ & $\begin{array}{l}\text { Asyams, al-lail, al-jatsiyah,al- } \\
\text { kahfi, al-isra',yunus }\end{array}$ \\
\hline 8 & $\begin{array}{l}\text { Ajakan untuk memikirkan alam semesta } \\
\text { sehiungga muncul keyakinan bahwa } \\
\text { sunnatullah pasti terjadi }\end{array}$ & $\begin{array}{l}\text { Al-innfithar, yasin, an-nazi'at,adz- } \\
\text { zariyat, al-isra, an-nahl }\end{array}$ \\
\hline
\end{tabular}

\section{Pemaknaan Simbolik Ayat-Ayat tentang Kiamat dan Kebangkitan}

Membaca Alquran artinya membuka lapisan-lapisan makna yang menyelubungi sebuah konsep dan gagasan Tuhan yang universal. Para pakar balâghah melihat bahwa rahasia kemu'jizatan sastra Alquran tidak terletak pada makna tekstualnya (makna tingkat pertama), melainkan pada makna tingkat keduanya (makna kontekstual). Berkaitan dengan ayat-ayat eskatologis, maka ia tidak hanya dipahami dalam tataran makna tingkat pertama. Pemahaman pada tingkat makna pertama akan membawa pembaca kepada eksplorasi detil-detil peristiwa dan informasi yang diungkapkan oleh Alquran tentang kiamat, kebangkitan, surga, dan neraka secara teologis dogmatis.

Dalam upaya fungsionalisasi Alquran maka perlu dilakukan pembacaan ayat-ayat eskatologis dengan menggunakan makna tingkat kedua, sehingga deskripsi tentang kiamat, kebangkitan, surga, dan neraka tersebut dapat membangkitkan spirit keagamaan yang konstruktif dan progresif dalam diri setiap pembacanya. Dengan menggunakan perspektif ini, maka ayat-ayat eskatologis akan terus menjadi sumber 
inspirasi bagi setiap mu'min dalam menata kehidupan sosial budayanya sepanjang masa. Hal itu mengingat Alquran dalam menyampaikan kebenaran selalu menyatakannya melalui struktur bahasa yang membangkitkan persepsi rasa dan imaji-imaji mental (Haque, 2000, hal. 86).

Pembacaan pada tingkat makna kedua membawa kita kepada pembacaan kontekstual terhadap ayat-ayat eskatologis tersebut. Untuk itu Abu Zaid telah merumuskan beberapa langkah praktis yang bisa diikuti, sebagai berikut (Nur Ichwan, 2003, hal. 104):

1. Penggunaan interpretasi tematik meskipun tidak sepenuhnya. Caranya dengan mempertimbangkan ayat-ayat lain yang setema tetapi dengan tetap menghargai kekhasan masing-masing. Kekhasan tersebut bisa disebabkan oleh perbedaan konteks historis atau perbedaan konteks linguistik.

2. Analisis ayat-ayat itu untuk melihat level maknanya, apakah hanya menunjuk kepada fakta historis yang tidak bisa diinterpretasikan secara metaforis; atau makna yang menyaran pada fakta historis dan dapat diinterpretasikan secara metaforis; ataukah makna itu dapat diperluas berdasarkan atas signifikasi yang dapat diungkap dari konteks sosio kultural di mana teks itu berada.

3. Memperhatikan arah teks yang dibaca. Untuk itu perlu pengetahuan tentang konteks penurunan ayat, Makiyah dan Madaniyahnya ayat tersebut. Hal itu diperlukan untuk mengenali fakta-fakta tekstual atau gejala-gejala kebahasaan dari masing-masing ayat tersebut.

4. Mencari aspek-aspek yang tak terkatakan dalam teks tersebut. Hal ini dapat dipereoleh dengan pembacaan berulang-ulang dengan mempertimbangkan arah teks.

5. Melakukan kritik idiologis terhadap pembacaannya sendiri, sejauh mana idiologi dan kecenderungan-kecenderungan pragmatisnya berpengaruh dalam pembacaannya.

Untuk mendapatkan pemahaman simbolik tentang makna kiamat dan kebangkitan dalam Alquran maka perlu dilakukan analisis tekstual dan kontekstual terhadap ayatayat tersebut.

\section{Analisis Ayat-Ayat Tentang Kiamat}

a. Al-Haaqah 1-7 


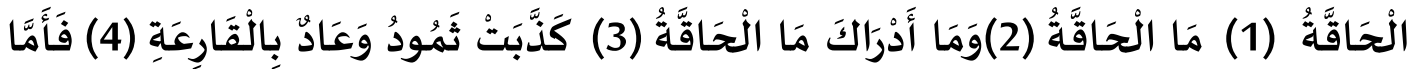

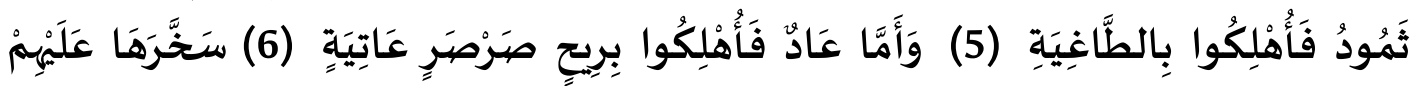

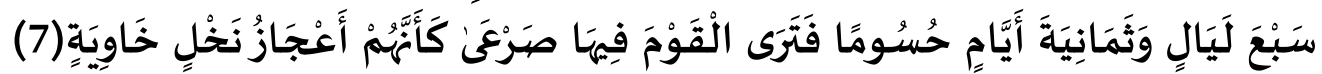

\section{1. hari kiamat,}

2. Apakah hari kiamat itu?

3. dan tahukah kamu Apakah hari kiamat itu?

4. kaum Tsamud dan 'Aad telah mendustakan hari kiamat.

5. Adapun kaum Tsamud, Maka mereka telah dibinasakan dengan kejadian yang luar biasa.

6. Adapun kaum 'Aad Maka mereka telah dibinasakan dengan angin yang sangat dingin lagi Amat kencang,

7. yang Allah menimpakan angin itu kepada mereka selama tujuh malam dan delapan hari terus menerus; Maka kamu Lihat kaum 'Aad pada waktu itu mati bergelimpangan seakan-akan mereka tunggul pohon kurma yang telah kosong (lapuk).

Ayat ini dimulai dengan penyebutan istilah kiamat dengan al-haaqqah dan pengulangan pertanyaan seputarnya. Al Haaqah menurut bahasa berarti yang pasti terjadi, hari kiamat dinamai Al Haaqqah karena dia pasti terjadi. Setelah mengenalkan istilah al-haaqah surat ini kemudian berbicara tentang beberapa kaum yang binasa dan mengalami akhir yang tragis akibat pengingkaran terhadap kiamat. Dalam surat ini kehancuran mereka disebabkan oleh angin topan dingin yang betiap sangat kencah hingga merontokkan mereka seperti daun-daun yang berguguran.

b. An-Najm 57-62

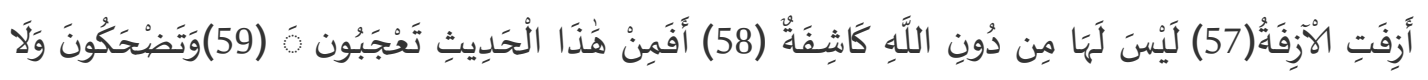

تَبَكُونَ 60 وَأَنتُمْ سَامِدُون (61 )فَاسْجُجُدُوا لِلَّهِ وَاعُبْدُوا (62)

57. telah dekat terjadinya hari kiamat.

58. tidak ada yang akan menyatakan terjadinya hari itu selain Allah.

59. Maka Apakah kamu merasa heran terhadap pemberitaan ini?

60. dan kamu mentertawakan dan tidak menangis?

61. sedang kamu melengahkan(nya)?

62. Maka bersujudlah kepada Allah dan sembahlah (Dia).

Dalam surat ini manusia diberi peringatan bahwa kiamat sudah dekat. Ia terjadi sesuai dengan ketentuan (takdir) Allah, dan pasti terjadi karena merupakan sunnatullah. Meskipun kiamat merupakan ketentuan Allah yang pasti banak manusia yang lalai dan abai terhdapnya, sehingga mereka lupa untuk berbakti dan patuh kepada Allah.

d. Al-Waqiah 1-9 


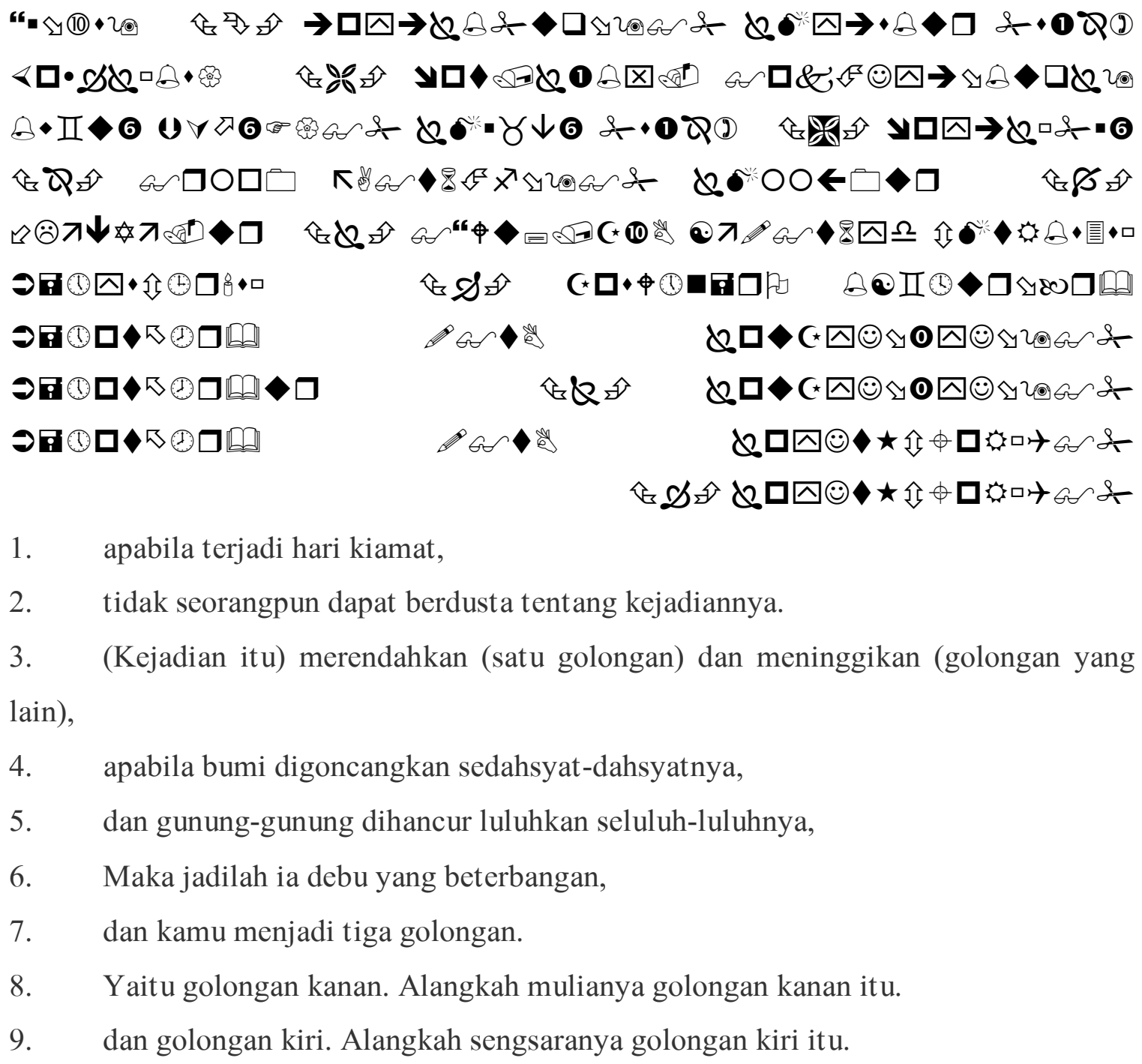

1. apabila terjadi hari kiamat,

2. tidak seorangpun dapat berdusta tentang kejadiannya.

3. (Kejadian itu) merendahkan (satu golongan) dan meninggikan (golongan yang lain),

4. apabila bumi digoncangkan sedahsyat-dahsyatnya,

5. dan gunung-gunung dihancur luluhkan seluluh-luluhnya,

6. Maka jadilah ia debu yang beterbangan,

7. dan kamu menjadi tiga golongan.

8. Yaitu golongan kanan. Alangkah mulianya golongan kanan itu.

9. dan golongan kiri. Alangkah sengsaranya golongan kiri itu.

Surat al-Waqiah mendeskripsikan kiamat seperti hancurnya gunung. Letusan gunung yang diawali dengan guncangan gempa tektonik begitu dahsyat, sehingga membuat materi gunung tersebut hancur berkeping-keping. Peristiwa kiamat tersebut akan membinasakan sebagian penduduk bumi, dan akan membiarkan beberapa penduduk yang lain selamat.

e. Al-Qiyaamah 1-15

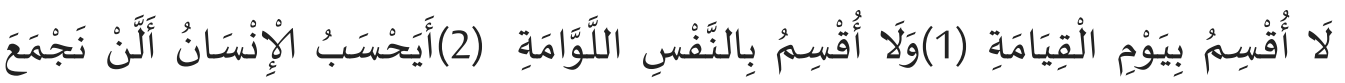

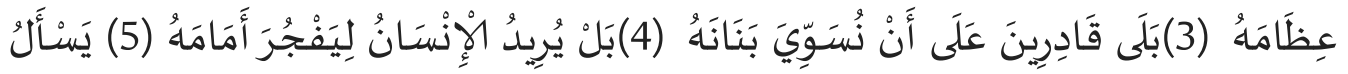

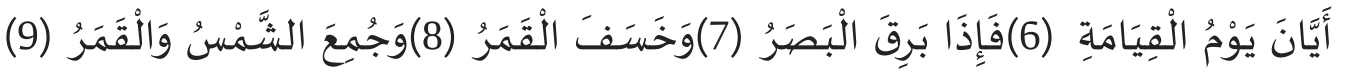

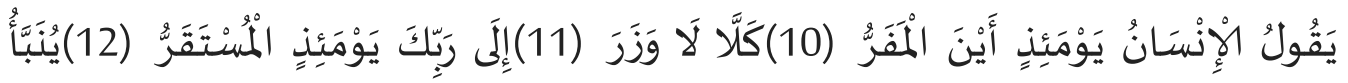




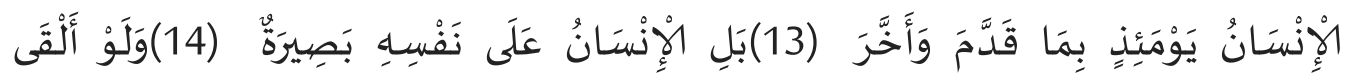

مَعَاذِيرَهُ (15)

1. aku bersumpah demi hari kiamat,

2. dan aku bersumpah dengan jiwa yang amat menyesali (dirinya sendiri)

3. Apakah manusia mengira, bahwa Kami tidak akan mengumpulkan (kembali) tulang belulangnya?

4. bukan demikian, sebenarnya Kami Kuasa menyusun (kembali) jari jemarinya dengan sempurna.

5. bahkan manusia itu hendak membuat maksiat terus menerus.

6. ia berkata: "Bilakah hari kiamat itu?"

7. Maka apabila mata terbelalak (ketakutan),

8. dan apabila bulan telah hilang cahayaNya,

9. dan matahari dan bulan dikumpulkan,

10. pada hari itu manusia berkata: "Ke mana tempat berlari?"

11. sekali-kali tidak! tidak ada tempat berlindung!

12. hanya kepada Tuhanmu sajalah pada hari itu tempat kembali.

13. pada hari itu diberitakan kepada manusia apa yang telah dikerjakannya dan apa yang dilalaikannya.

14. bahkan manusia itu menjadi saksi atas dirinya sendiri

15. meskipun Dia mengemukakan alasan-alasannya.

Surat ini menggambarkan kiamat sebagai gerhana yang membuat bumi menjadi gelap, ketika itu manusia akan kebingungan mencari arah. Kegelapan total membuat manusia berlari ke sana kemari karena kebingungan bercampur takut. Dalam keadaan bingung dan takut itulah manusia akan menyadari dengan fitrahnya bahwa mereka butuh perlindungan. Setelah dilanda ketakutan, barulah manusia menyadari kesalahankesalahan yang pernah mereka lakukan.

Secara teologis umat Islam meyakini bahwa kiamat pasti akan datang, namun tidak ada yang tahu kapan datangnya hari kiamat itu. Hari kiamat adalah hari berakhirnya kehidupan dunia yang fana, pada hari itu bumi di goncangkan dengan goncangan yang sangat dahsyat dan mengeluarkan beban-beban berat yang di kandungnya (QS. Al Zalzalah/kegoncangan), gunung-gunung dihancur luluhkan menjadi debu yang berterbangan (QS. AL Waqi'ah, 5-6) Matahari di gulung, bintang-bintang berjatuhan (QS. At Takwir, 1,2,3,6 dan 11).

Melalui analisis mendalam terhadap konteks tekstual dan historis ayat-ayat tentang kiamat dapat diketahui bahwa salah satu tanda kiamat adalah kerusakan akhlak, hilangnya cita-cita luhur dan lenyapnya nilai (Hanafi , 2013, hal. 376). Kehidupan bangsa Arab khususnya bangsa Quraisy, yang berorientasi pada materialisme dan 
pragmatisme menyebabkan kurangnya perhatian terhadap aspek nilai dan moral. Perilaku politik, sosial, dan ekonomi, bahkan termasuk perilaku keagamaan bangsa Arab kala itu sangat kental diwarnai dengan kepentingan-kepentingan duniawi. Di sisi lain, dominasi materialisme mengakibatkan munculnya benih-benih konflik di antara mereka. Konflik horisontal antar para pedagang, elit politik, dan konflik vertikal, antara kaum elit dan rakyat biasa.

Mayoritas ulama sepakat bahwa deskripsi naratif Alquran tentang kiamat, merupakan indzar (peringatan) atau tarhib (upaya untuk membuat pembaca menjadi takut). Melalui narasi kiamat Alquran mengajak pembaca untuk melakukan pengamatan kritis terhadap fenomena sosial budaya yang telah mengalami kemerosotan moral dan kehilangan visi kemanusiaan. Kemerosotan dan kemunduran moral tersebut merupakan warning tentang kehancuran sebuah tatanan sosial, peradaban, bahkan eksistensi sebuah bangsa.

Beberapa tanda-tanda kiamat lain menyaran akan adanya kesalahan dan problematika dalam suatu tatanan sosial budaya yang menjadi ancaman bagi keberlangsungan suatu bangsa. Tanda-tanda tersebut antara lain :

a. Peternak membangun bangunan tinggi, ini menyaran adanya alghurur atau miss macth dalam menempatkan orang, atau orang bodoh berbuat seolah-olah orang pintar, atau orang adil dianggap zhalim, kesemuanya merupakan akibat kepentingan politik yang menyuburkan sikap munafik (Hanafi , 2013, hal. 376).

b. Anak-anak kecil tidak menjadi tua, seolah-olah zaman berhenti yang mengindikasikan tidak adanya pertumbuhan, perkembangan, pembangunan dan dinamika kehidupan, atau banyak anak-anak mati sebelum dewasa karena kelaparan dan perang (Hanafi , 2013, hal. 377).

c. Sungai Eufrat menjadi surut dan di dalamnya ditemukan perbendaharaan emas namun tidak seorangpun mengambilnya, artinya tidak ada orang yang dapat memanfaatkan hasil sumber daya alam. Karena kebodohan mereka tidak dapat merencanakan pembangunan dan memanfaatkan sumber daya alam (Hanafi , 2013, hal. 377).

Hari kiamat sering disebut dengan yaumul ma'ad (hari kembali) untuk menunjukkan adanya harapan kembali ke Makkah (GIBS, 2013, hal. 849). Makkah merupakan tanah leluhur Nabi, sekaligus menjadi negeri harapan. Wacana tentang yaumul ma’ad merupakan wacana pengharapan, bahwa perjuangan nabi bersama 
perngikutnya selama 23 tahun bertujuan untuk kembali ke Mekkah, negeri yang diberkahi.

Secara simbolik kiamat menunjukkan adanya masa transisi, berpindahnya umat manusia dari kehidupan alam dunia menuju alam akhirat (Hamid, hal. 437). Tanda-tanda dan episode kiamat merupakan pengimajinasian dan penggambaran seni tentang perasaan terhadap “ending”, kerusakan akhlak, munculnya fitnah/konflik, kerusakan aturan alam. Ia juga memberikan imajinasi terhadap permulaan alam yang baru, harapan yang berkelanjutan, keadilan abadi pasca kebinasaan. Pendek kata ia menggambarkan dunia perasaan nyata dalam bentuk imajinasi (Hanafi , 2013, hal. 376).

Ungkapan imajinasi menggunakan deskripsi yang sangat realistik banyak diketemukan dalam ayat-ayat AlQuran. Melalui deskripsi imajinatif maka kiamat seolah-olah terlihat di depan mata, sebagai mana diriwayatkan oleh Abdullah ibn Umar :

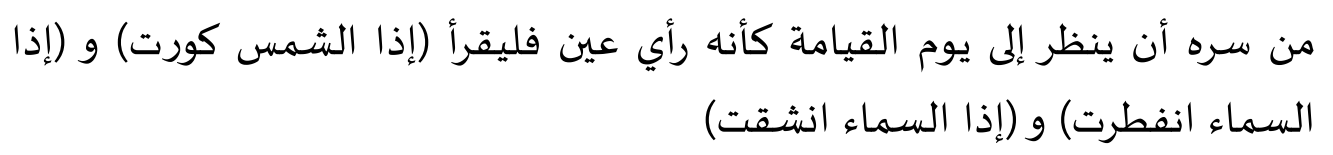

Deskripsi realistis tentang kiamat membuat pembaca dapat merasakan bahwa kehancuran sistem jagat raya yang berwujud materi ini pasti akan terjadi. Bahkan mungkin pembaca bisa berimajinasi seolah-olah peristiwa tersebut sedang terjadi (Salman bin Fahd Al-Audah, Tajribah At-Takhayyul Alqurani).

Selain tentang kiamat, Alquran juga menguraikan masalah kebangkitan secara panjang lebar dengan menggunakan beberapa metode dan pendekatan. Kata “ al-yaum al-ākhir" yang terulang sebanyak $24 \mathrm{kali}$, di samping kata "ākhirāt" yang terulang sebanyak 115 kali serta beberapa kata-kata padanannya, menunjukan betapa besar perhatian Alquran dan betapa pentingnya konsep kebangkitan dalam mind set keberagamaan (Shihab, 2007, hal. 109).

Secara teologis, kebangkitan adalah peristiwa terakhir dari perjalanan hidup manusia . Hari kebangkitan adalah kulminasi semua peristiwa kiamat, baik yang kecil maupun yang besar. Peristiwa ini hanya sekali dan menandakan dimulainya alam besar, yang lebih besar dan agung dari seluruh tingkatan alam semesta ini. Hari kebangkitan akan datang dengan tiba-tiba. Pada saat itu, semua manusia dari seluruh generasi akan dihidupkan kembali, lalu diadili sesuai dengan perbuatan yang mereka lakukan semasa hidup di dunia.

Hari kebangkitan atau pertanggung jawaban manusia yang terakhir, adalah sebuah ide yang sangat sulit untuk diterima oleh orang-orang Mekkah-Jahiliyah yang 
berpandangan sekuler (Rahman , 1983, hal. 168). Di antara berbagai macam sifat yang menjadi ciri khas semangat zaman Jahiliyah antara lain adalah "keduniaan" (Izutsu , 1993, hal. 54). Oleh karena itu, pesan wahyu yang dibawa Nabi kepada kaumnya tentang hari kebangkitan dan dunia yang akan datang telah menimbulkan cemoohan dan ejekan (Izutsu, 1997, hal. 94).

Menurut Alquran, hari kebangkitan sangat penting karena berbagai alasan. Pertama, moral dan keadilan sebagai konstitusi realitas menurut Alquran adalah kualitas untuk menilai perbuatan manusia, karena keadilan tidak dapat dijamin berdasarkan apaapa yang terjadi di atas dunia. Kedua, tujuan-tujuan hidup harus dijelaskan dengan seterang terangnya sehingga manusia dapat melihat apa yang telah diperjuangkannya dan apa tujuan-tujuan yang sesungguhnya dari kehidupan ini. Ketiga, yang sangat erat kaitannya dengan alasan kedua: perbantahan, perbedaan pendapat, dan konflik di antara orientasi orientasi manusia akhirnya harus diselesaikan (Rahman , 1983, hal. 169).

Sementara itu, menurut Abd. Rahman Dahlan, ada tujuh cara Alquran untuk memastikan terjadinya hari kebangkitan: Pertama, Alquran mendeskripsikan peristiwaperistiwa yang akan terjadi pada hari kebangkitan sebagai pembalasan semua amal perbuatan manusia. Kedua, bersumpah dengan hari kebangkitan. Allah bersumpah dengan menggunakan hari kebangkitan sebanyak tiga kali, misalnya dalam surat alQiyāmah ayat 1. Ketiga, menjelaskan bahwa kebangkitan terjadi karena kekuasaan Allah. Keempat, menjelaskan bahwa hari kebangkitan merupakan perulangan penciptaan manusia. Kelima, membangkitkan manusia adalah merupakan hal mudah bagi Allah. Keenam, siksa yang ditimpakan Allah di dunia merupakan contoh siksa akherat. Ketujuh, mengemukakan contoh tentang cara Allah menghidupkan orang yang telah mati (Rahman D, 1997, hal. 267-270).

Alquran menegaskan tentang kepastian akan datangnya hari kebangkitan karena sikap bangsa Arab yang abai terhadap pertimbangan-pertimbangan moral dalam sepak terjang mereka. Sesungguhnya Tuhan telah mengajukan argumentasi dari berbagai sudut pandang tentang kepastian adanya hari kebangkitan agar mereka bisa memiliki tanggung jawab moral bagi eksistensi kehidupan umat manusia. Sejalan dengan tujuan di atas, maka Alquran membangun argumentasi tentang urgensi keyakinan terhadap akhirat, bermula dari argumen penciptaan alam dan penciptaan manusia. Setelah menjelaskan argumen penciptaan, Alquran pun mendeskripsikan tentang kisah-kisah umat terdahulu yang mengalami kebinasaan dan kehancuran akibat melalaikan nilai-nilai luhur dan 
moralitas. Ketika penjelasan tentang penciptaan dan gambaran tentang umat masa lalu telah disampaikan, barulah Alquran memberikan gambaran imajinatif masa depan tentang dampak yang akan terjadi ketika mereka tidak mau sadr untuk membangun moralitas luhur.

Secara simbolik, Alquran melalui pengenalan konsep al-yaum al-ākhir atau akhirat, serta konsep-konsep lain yang menyaran tentang hari kebangkitan mengajarkan pada pembaca bahwa segala sesuatu yang kita lakukan harus dipertanggung-jawabkan. Penghancuran budaya dan peradaban yang terjadi akibat kesalahan cara pikir dan mind set akan berdampak besar bagi kemanusiaan. Sebelum merusak kemanusiaan di masa yang akan datang, sebelum manusia terlanjur terjerumus dalam dekadensi moral, kemiskinan, dan konflik abadi, maka kita harus memiliki pertimbangan matang dalam bertindak dan bersikap.

\section{Analisis Ayat-Ayat Tentang Kebangkitan}

\section{a. Abasa 32-42}

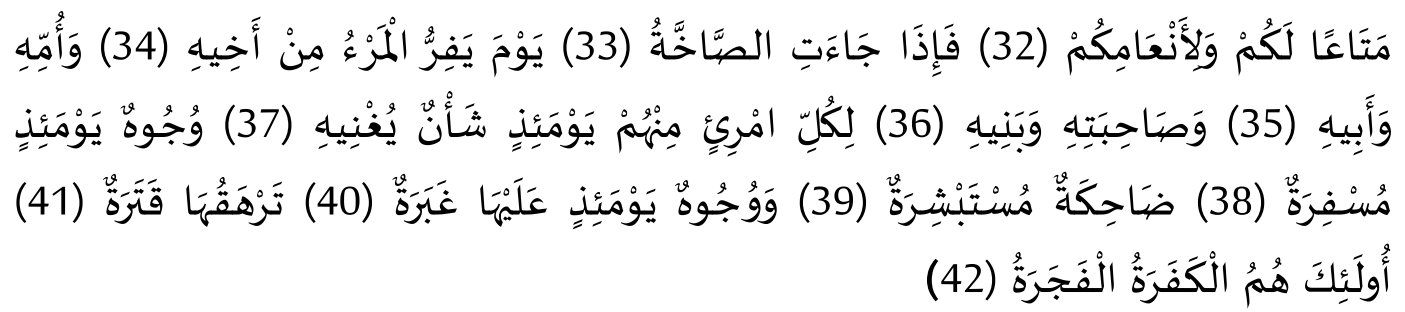

32. Untuk kesenanganmu dan untuk binatang-binatang ternakmu.

33. Dan apabila datang suara yang memekakkan (tiupan sangkakala yang kedua),

34. Pada hari ketika manusia lari dari saudaranya,

35. Dari ibu dan bapaknya,

36. Dari istri dan anak-anaknya.

37. Setiap orang dari mereka pada hari itu mempunyai urusan yang cukup menyibukkannya.

38. Banyak muka pada hari itu berseri-seri,

39. Tertawa dan bergembira ria,

40. Dan banyak (pula) muka pada hari itu tertutup debu,

41. Dan ditutup lagi oleh kegelapan

42. Mereka Itulah orang-orang kafir lagi durhaka.

Surat ini menjelaskan bahwa ketika kiamat terjadi, masing-masing individu bertanggung jawab terhadap dirinya masing-masing. Rasa persaudaraan dan kesetiakawanan menjadi pudar diakibatkan kesibukan duniawi. Manusiapun terbagi menjadi dua model, manusia-manusia yang mensikapi hari-harinya dengan senyuman dan wajah berseri-seri, atau manusia-manusia yang kusam dan hitam wajahnya. Mereka 
yang kusam dan ditutupi debu adalah orang-orang yang selama ini sibuk dengan dunia, lupa membangun relasi-relasi yang harmonis dengan sesama.

\section{b. An-Nazi'at 6-12}

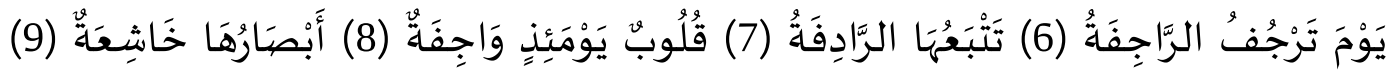

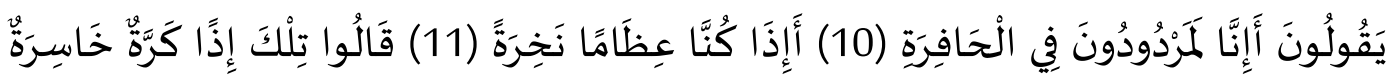

6. (Sesungguhnya kamu akan dibangkitkan) pada hari ketika tiupan pertama menggoncang Alam,

7. Tiupan pertama itu diiringi oleh tiupan kedua.

8. Hati manusia pada waktu itu sangat takut,

9. Pandangannya tunduk.

10. (orang-orang kafir) berkata: "Apakah Sesungguhnya kami benar-benar dikembalikan kepada kehidupan semula?

11. Apakah (akan dibangkitkan juga) apabila kami Telah menjadi tulang belulang yang hancur lumat?"

12. Mereka berkata: "Kalau demikian, itu adalah suatu pengembalian yang merugikan".

Alquran menggambarkan bahwa manusia baru tersadar bahwa mereka sudah melenceng dari ketentuan moral manakala terjadi goncangan hidup. Goncangan pribadi berupa problematika pribadi, ataupun goncangan sosial budaya berupa konflik, huruhara, peperangan dan sebagainya. Kondisi chaos sosial membuat manusia tertunduk malu dan lunglai, karena mereka dihadapkan pada tuntutan untuk mempertanggungjawabkan apa yang telah mereka lakukan.

\section{c. Yasin 61}

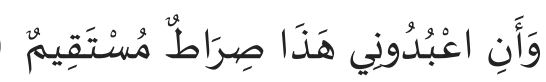

61. Dan ditiuplah sangkalala, Maka tiba-tiba mereka keluar dengan segera dari kuburnya (menuju) kepada Tuhan mereka.

Surat yasin menjelaskan bahwa meskipun manusia sudah mati dan dikubur di dalam tanah, ia akan dikembalikan kepada tuhannya. Makna ayat ini adalah bahwa segala perilaku dan sikap manusia akan dimintai pertanggungjawaban setelah dia meninggal. Segala perbuatannya akan memberikan dampak pada sesama dan generasi selanjutnya, itulah sebabnya manusia tidak akan dibiarkan mati tanpa pertanggungjawaban amal. 
Doktrin eskatologis bertujuan untuk membangun kesadaran akan tanggung jawab individu. Hal ini sekaligus mengoreksi pandangan suku-suku Arab yang meletakkan tanggung jawab kolektif atas setiap perbuatan seseorang. Setiap indivdu, menurut doktrin ini, akan mendapatkan hasil dari setiap tindakannya didunia. Pertanggungjawaban tersebut akan terjadi pada kehidupan setelah mati. Sasaran reformasi dari ajaran eskatologis ini adalah penegakan moral dalam setiap perbuatan manusia. Dalam masyarakat yang materialistis, aspek moral menjadi sesuatu yang tidak pernah disentuh. Akibatnya, system sosial yang berlaku menampakkan adanya stratifikasi. Stratifikasi ini berimbas pada segala aspek kehidupan, baik ekonomi, politik, maupun social (Sodiqin, 2008, hal. 89-90).

Kisah-kisah emansipatoris di dalam Alquran juga merupakan salah satu metode yang dipergunakan untuk menjelaskan adanya kehancuran dan kebangkitan. Kehancuran suatu kaum diakibatkan kedurhakaan mereka terhadap Allah dan para rasul. Ketika sebuah peradaban hancur, maka Allah akan memunculkan peradaban baru yang mengantikan kaum sebelumnya. Kebangkitan, apabila dikaitkan dengan kisah-kisah Nabi tidak terjadi di hari akhirat. Kebangkitan dalam konteks ini menyaran pada adanya harapan untuk membangkitan peradaban yang lebih baik. Gambaran tentang kaum yang hancur menunjukkan bahwa kehancuran kiamat adalah kehancuran peradaban. Pemaparan kisah-kisah kehancuran dalam Alquran bertujuan untuk mengkritik situasi kondisi yang ada, sekaligus untuk memperingatkan ending yang akan terjadi bila mereka tetap dalam keadaan seperti itu.

Doktrin tentang kebangkitan merupakan upaya untuk mereformasi kondisi moral masyarakat. Penerimaan akan realitas adanya hari akhir berhubungan dengan realisasi akan realitas adanya keadilan tuhan. Keyakinan terhadap kehidupan setelah mati dapat mendorong orang untuk berbuat kebajikan. Dari ajaran ini, akan dihasilkan tatanan kehidupan yang bermoral (Sodiqin, 2008, hal. 86-88).

\section{Kesimpulan}

Hasil Penelitian menunjukkan bahwa ayat-ayat eskatologis dalam Alquran di samping memiliki makna tekstual-teologis memiliki makna simbolik. Pemaknaan teologis mengandaikan bahwa peristiwa-peristiwa kiamat, kebangkitan, kehidupan syurga dan neraka adalah wilayah keimanan yang harus diyakini sebagai peristiwa nyata yang sifatnya ghaib. Sedangkan pemaknaan simbolik menyaran pada pemahaman bahwa ayat-ayat tersebut diuturnkan dalam konteks budaya dan situasi kondisi kesejarahan 
tertentu yang memungkinkan pembacaan terhadap konsep-konsep eskatologis tersebut secara kontekstual.

Ayat-ayat tentang kiamat sebagai kehancuran kehidupan, dan akhirat sebagai wahana untuk pertanggungjawaban menyarankan adanya kritik sosial terhadap kondisi sosial-budaya mayarakat. Kiamat dan kebangkitan mendorong pembaca untuk mawas diri dan menyadari tentang situasi di mana mereka berada, sehingga mereka dapat memperbaiki setiap kesalahan dalam komponen peradaban yang mereka bangun selama ini.

Penelitian ini diharapkan dapat ditindaklanjuti dengan penelitian-penelitian lain dengan menggunakan perspektif tafsir tematik untuk menemukan konsep-konsep Alquran tentang masyarakat ideal. Penelitian model ini diharapkan dapat menemukan teori-teori sosial-budaya baru berbasis Alquran.

\section{Daftar Pustaka}

Abdalla, U. A. (2005). Menjadi Muslim Liberal. Jakarta: Nalar.

Ahimsa, H. S. (2001). Strukturalisme Levi Strauss Mitos dan Karya Sastra. Yogyakarta: Galang Press.

Akyol, M. (2014). Islam tanpa Ekstrimisme. Jakarta : Alex Media Komputindo .

Al bana, J. (2008). Al Islam Dien Wa Ummah Wa Laisa Dienan Wa Daulah. Beirut: Dar Asyuruq.

Al-Hariri, A. (1985). Nabi Ar-Rahmah wa Al-Quran Al-Muslimin,. Beirut: Bahts fi mujtama' Makkah.

Ali al-Mashhur, A. B.-A. (2015). Dawāir al- 'Iaadah wa Marātib al-Ifādah. Yaman: Daralmueein.

Ali Salamah, A. (1994). Quraisy qabla Al-Islam dauruha As-Siyasiy wa al-Iqtishodi wa ad-Dini. Riyadh: dar al mirikh.

Al-Qathan, M. (t.thn.). Mabâhits fì 'Ulûm al-Qur'ân.

Amin, A. (1975). Fajr Al Islâm. Beirut: Dar Al Fikr.

Assyaukanie, L. (2007). Islam Benar Versus Islam Salah. Depok: Kata Kita.

Badwi, A. (t.thn.). Min Balâghah Al Qur'an. Kairo: Dar Nahdhoh Mishr.

Burhani , A. (2001). Islam Dinamis. Jakarta: Kompas.

Cobley , P. (2002). Semiotika For Beginners. Bandung: Mizan.

Creswell, J. (t.thn.). Research Design: Quantitative and Qualitative Approach. California: Sage Publication Ins.

Dzu'biy, Z. (u.d.). Binyahat-Tamtsil wa fa'iliyah at-Takhyil fi Al-Quran Al-Karim. Dar Almamdhumah: Dirosat al'ulum al-Insaniyah wa al-ijtima'iyah al-urdun.

Eriyanto. (2001). Analisis Wacana. Yogyakarta: LKiS.

Fahd Al-Audah, S. (u.d.). WwW.islamtoday.net. Hämtat från Tajribah At-Takhayyul AlQurani.

GIBS, H. (2013). Al-Maushu'ah Al-Islamiyah Al-Muyasaroh. Kairo: Alhai'ah AlMishriyah AlAmah.

Hadiyanto, A. (2015). Berbagai Pembacaan Al-Qur'an Kontemporer. Jurnal Studi AlQur'an. https://doi.org/https://doi.org/10.21009/JSQ.011.1.01, 11(1). 
Hamid, S. R. (t.thn.). Pintar Islam. Bogor: Cahaya Islam.

Hanafi , H. (2013). Min An-Naql ila al-Aql, juz 2. Kairo: al HAi'ah al-Mushriyah al ammal.

Haniff Hassan , M. (2006). Pray to Kill. Jakarta: Grafindo.

Haque, Z. (2000). Wahyu dan Revolusi. Yogyakarta: LkiS.

Hasan , T. (1985). Al Lughah al Arabiyah Ma'naha wa Mabnaha. Mesir: Al Haiah al Mishriyah li al Kutub.

Hasan, H. M. (1993). al Lughah wa at Tafkir. Beirut: : Dar Al Fikr.

Hidayat, R. (1989). Taufik Khazanah Istilah Al-Qur'an (1 uppl.). Bandung: Mizan.

Hidayat, K. (u.d.). Memahami bahasa Agama.

Ichwan, M. (2003). Meretas Kesarjanaan Kritis Al-Qur'an Teori Hermeneutika Nasr Abu Zayd. Jakarta: Teraju.

Irwandar. (2003). Demitologisasi Adam dan Hawa. Jogjakarta : Arruz Press.

Izutsu, T. (1993). Konsep-Konsep Etika Religius Dalam Qur'an. Yogyakarta: Tiara Wacana.

Izutsu, T. (1997). Relasi Tuhan dan Manusia. Yogyakarta: Tiara Wacana.

Ma'arif, S. (26-30 Nopember 2006). Islam dan Pendidikan Pluralisme, makalah disampaikan pada annual. Conference Kajian Islam di Lembang.

Mahayana, M. (den 30 Oktober 2008). http://mahayana-mahadewa.com/?p=159. Hämtat från Analisis Struktural Terhadap Cepen Gerson Poyk. den 20 November 2008

Mahliatussikah , H. (den 1 Juni 2003). “Analisis Struktural Semiotik Dalam Puisi Arab Modern "Kun Jamîlan” Karya Eliya Abu Madhi”. Jurnal Al Arabi, 1.

Mushaf Al-Qur'an, Lajnah Pentashihan. (u.d.). Tafsir AlQur'an Tematik . Jakarta: Kamil Pustaka.

Muslim, M. (2000). Mabahitsfi at-Tafsir al-maudhui. Damaskus: Darul Qolam.

Nabi , M. (2000). Az-Zhohiroh al-Quraniyah. Beirut: Darul Fikr.

Nashir , H. (2013). Islam Syariat. Bandung: Mizan.

Nasr, S. (2002). The Heart of Islam: Enduring Values for Humanity. New York: HarperCollin.

Nur Ichwan, M. (2003). Meretas Kesarjanaan Kritis Al-Qur'an Teori Hermeneutika Nasr Abu Zayd.

Nurgiyantoro, B. (1998). Teori Pengkajian Fiksi. Yogyakarta: Gajah Mada University Press.

Pateda, M. (2001). Semantik Leksikal. Jakarta: Rioneka Cipta.

Pradopo, R. D. (2001). Penelitian Sastra dengan Pendekatan semiotik dalam Jabrohim, Metodologi Penelitian Sastra. Yogyakarta: Hanindita.

Pradopo, R. D. (2001). Penelitian Sastra dengan Pendekatan semiotik dalam Jabrohim: Metodologi Penelitian Sastra. Yogyakarta: Hanindita.

Pradopo, R. D. (2002). Kritik sastra Indonesia Modern. Yogyakarta: GAMA Media.

Rahim, H. (2001). Arah Baru Pendidikan Islam di Indonesia. Jakarta: Logos Wacana Ilmu.

Rahman , F. (1983). Tema Pokok Al-Qur'an. Jakarta: Pustaka.

Rahman D, A. (1997). Kaidah-Kaidah Penafsiran Al-Qur'an. Bandung: Mizan.

Sahrur, M. (2000). Al Qur'an wa Al Kitab. Beirut: Syarikah al Mathbu'at.

Sall, C. (2005). tathowur al-Quran at-Tarikhi. Beirut.

Santosa, P. (1993). Ancangan Semiotika Dan Pengkajian Susastra. Bandung: Angkasa.

Santoso, R. (2003). Semiotika Sosial. Jakarta: Pustaka Eureka. 
Sastro, P., \& RA Santoso. (1987). Pendapat Publik, Pendapat Umum, dan Pendapat Khalayak Dalam Komunikasi Sosial. Bandung: Remadja Karya.

Shihab, M. (2007). Wawasan Al-Qur'an. Bandung: Minaz.

Siddiqi, M. (1994). The Qur'anic Concept of History. New Delhi: Adam Publisher and Distributors.

Sobur, A. (2003). Semiotika Komunikasi. Bandung: Remaja Rosda Karya.

Sodiqin, A. (2008). Antropologi Al Qur'an. Yogyakarta: Arruz Media Group.

Sodiqin, A. (2008). Antropologi Al-Qur'an Model Dialektika Wahyu Dan Budaya.

Sukidi. (2001). Teologi Inklusif Cak Nur. Jakarta: Kompas.

Sukiman , U. (2003). Ikonitas dalam Novel Hamamah Salam Karya Najib Al Kailani. Jurnal Adabiyat, 1.

Suprayogo , I., \& Tobroni. (2001). Metodologi Penelitian Sosial-Agama. Bandung: PT. Rosdakarya.

Suprayogo, I. (2001). Metodologi Penelitian Sosial Keagamaan. Bandung: Remaja Rosda Karya.

Wijaya, A. (2016). Metode Tafsir Nuzuli Darwazah. Bandung: Mizan. 